\title{
PENYISIPAN GEN WARNA PADA IKAN Carassius auratus MENGGUNAKAN METODE ELEKTROFORASI DALAM UPAYA MENINGKATKAN KUALITAS IKAN HIAS
}

\author{
Wartono Hadie"), Eni Kusrini" ${ }^{* *}$, Agus Priyadi"*), dan Alimuddin $\left.{ }^{* * *}\right)$ \\ *) Pusat Penelitian dan Pengembangan Perikanan Budidaya \\ Jl. Ragunan 20, Pasar Minggu, Jakarta Selatan 12540 \\ E-mail:tono_hadi@yahoo.com \\ **) Balai Riset Budidaya Ikan Hias \\ Jl. Perikanan No. 13, Pancoran Mas, Depok \\ ***) Institut Pertanian Bogor \\ Jl. Lingkar Kampus, Kampus IPB Darmaga, Bogor 16680
}

(Naskah diterima: 21 Januari 2010; Disetujui publikasi: 30 September 2010)

\begin{abstract}
ABSTRAK
Tujuan penelitian ini adalah untuk mendapatkan teknik rekayasa penyisipan gen warna pada ikan hias dan pengetahuan tentang pola pewarisannya yang akan dapat membantu perbaikan mutu ikan. Metode yang diterapkan adalah elektroforasi. Ikan hias yang digunakan dalam penelitian adalah ikan komet (Carassius auratus) sedangkan gen pemendar yang digunakan adalah GFP (green fluorescent protein) dengan konstruksi DNA yang digunakan berbentuk plasmid yang dikontrol oleh promoter $\beta$-aktin dari ikan Japanese flounder (ikan sebelah) dengan panjang fragmen pKer-GFP 6,0 kb. Sintasan dan keberadaan gen GFP diamati mulai dari telur menetas. Ekspresi gen dapat diamati setelah fase terbentuknya sirip dan dilakukan secara deskriptif (performa) dan PCR. Hasil yang diperoleh gen GFP terekspresi mulai pembentukan sirip dan hasil cek PCR semua ketiga konsentrasi DNA yang dicobakan mempunyai ekspresi yang sama. Untuk dapat mengetahui ekspresi gen GFP sampai pada $F_{0}$ masih menunggu ikan dewasa dan matang gonad.
\end{abstract}

KATA KUNCI: elektroforasi, GFP, promoter $\beta$-actin, Carassius auratus

ABSTRACT: Insertion of green fluorescent protein to Carassius auratus using electroporation method to increase the quality of ornamental fish. By: Wartono Hadie, Eni Kusrini, Agus Priyadi, and Alimuddin

This research was aimed to obtain a method for introduction of exogenous gene of green flourescent protein (GFP) in order to improve the ornamental fish color appearance. The method used were electroporation. The Carassius auratus were used in this research. The construct of flourescent gene of pKer-GFP as DNA construct of plasmid controlled by $\beta$-actin of Japanese flounder with pKer-GFP $6.0 \mathrm{~kb}$ in length. Survival rate and gene expression of GFP assessed right after the eggs hatched. Gene expression was observed using PCR product and direct observation. The result show that the expression of GFP from all of three treatments were observed but not significantly different. This expression however should be wait until the fish mature.

Keywords: $\quad$ electrophoration, GFP, promoter $\beta$-actin, Carassius auratus 


\section{PENDAHULUAN}

Trend perdagangan ikan hias dari sisi tujuan pasar, masih menghadapi tantangan karena ikan hias sebagai komoditas "costumer base". Artinya pola perdagangannya dipengaruhi oleh selera konsumen. Hasil survai terakhir di pasar utama (AS dan UE) menunjukkan bahwa konsumen ikan hias mayoritas di kalangan remaja usia 11-15 tahun. Berdasarkan hasil ini menunjukkan bahwa kreativitas dan inovasi diperlukan untuk menarik mayoritas konsumen baik yang terkait dengan pengembangan teknologi akuarium dan perlengkapannya maupun pengembangan spesies ikan jenis baru.

Gen pemendar warna, khususnya pemendar warna hijau (GFP = green fluorescent protein) telah ditemukan sebagai bahan dasar pemendar pada tubuh ikan. Penggunaan bahan dasar tersebut telah berhasil mengubah ikan menjadi warna yang menarik dan mempunyai nilai jual tinggi. Setelah menyisip ke genom ikan inang melalui transfer gen (transgenesis), gen tersebut dapat diwariskan kepada generasi berikutnya melalui mekanisme pewarisan sifat. Namun demikian pola pewarisan hendaknya dipelajari sehingga dapat diperhitungkan pada proses produksi massalnya.

Kinoshita \& Ozato (1995) mengembangkan cara penyisipan gen adalah melalui injeksi ke dalam nukleus oosit. Pada tikus, penyisipan DNA ini melalui nukleus dari telur yang telah dibuahi. Namun pada ikan hal ini lebih sulit karena telur ikan yang sudah dibuahi, kadangkadang memiliki korion yang tebal, sehingga sulit untuk mencapai nukleus. Namun demikian beberapa tahun terakhir, teknik injeksi sitoplasma ke dalam telur yang telah dibuahi telah dikembangkan di beberapa laboratorium. Metode lain yang bisa digunakan adalah elektroforasi dan lipofeksi (Hackett, 1993). Dengan menggunakan kedua metode terakhir ini, transfer gen dapat dilakukan secara massal melalui sperma, telur, atau embrio.

Transgenesis sangat bermanfaat dalam berbagai macam studi tentang biologi (Jaenisch, 1988 dalam Meng et al., 1999). Misalnya studi mengenai fungsi dan pola ekspresi dari gen serta untuk memproduksi produk komersial yang diinginkan (Kinoshita \& Ozato, 1995). Di bidang perikanan budidaya, transfer DNA eksogenous umumnya ditujukan untuk memproduksi galur transgenik yang mempunyai nilai komersial lebih tinggi (GarciaPozo et al., 1998). Perkembangan teknologi transgenik ikan di dunia meningkat dengan cepat. Keuntungan ekonomi yang potensial dari teknologi transgenik ikan ini tidak diragukan lagi. Ikan transgenik bisa juga digunakan sebagai bioreaktor untuk memproduksi bahan-bahan yang bersifat komersial maupun yang bermanfaat bagi kesehatan (Collas et al., 2000).

Tujuan dalam penelitian ini adalah untuk mengetahui keberhasilan metode elektroforasi dalam penyisipan gen pemendar warna hijau (GFP) pada ikan komet.

\section{BAHAN DAN METODE}

Penelitian dilakukan di Balai Riset Budidaya Ikan Hias, Depok dan Laboratorium Reproduksi dan Genetika Organisme Akuatik, IPB. Bahanbahan yang digunakan dalam penelitian ini antara lain: ovaprim, larutan fisiologis, dan induk ikan hias (komet, maskoki, dan sinodontis). Konstruksi DNA yang digunakan berbentuk plasmid yang dikontrol oleh promoter keratin dari ikan Japanese flounder dengan panjang fragmen pKer-GFP-N1 6,0 kb.

Pemijahan ikan uji dilakukan dengan sistem buatan, induk betina dan induk jantan yang telah matang gonad disuntik ovaprim (dosis $0,5 \mathrm{~mL} / \mathrm{kg}$ ). Setelah 12 jam dari waktu penyuntikan, induk di-striping untuk mendapatkan telur dan sperma dari induk jantan.

Spermatozoa dari beberapa induk jantan dikumpulkan dalam microtube, yang selanjutnya dicampur dengan $25 \mu \mathrm{L}$ DNA dan dimasukkan ke dalam mesin elektroforator untuk dilakukan kejutan dengan voltase yang berbeda. Perlakuan yang digunakan adalah kejutan dengan $50 \mathrm{mV} / \mathrm{s}, 75 \mathrm{mV} / \mathrm{s}$, dan 100 $\mathrm{mV} / \mathrm{s}$. Spermatozoa hasil dari kejutan listrik tersebut langsung dicampur dengan larutan fisiologis sebanyak $625 \mu \mathrm{L}$, diaduk kemudian dipindahkan ke dalam tabung baru untuk persiapan pembuahan. Telur hasil pembuahan buatan dari sperma yang diperlakukan dengan elektroforasi segera diinkubasikan ke dalam akuarium hingga menetas.

Motilitas sperma diamati menggunakan mikroskop, yaitu menghitung jumlah spermatozoa yang aktif. Spermatozoa yang diamati adalah spermatozoa sebelum dan setelah diperlakukan dengan elektroforasi. Motilitas spermatozoa diukur dengan menghitung jumlahnya yang aktif bergerak. 


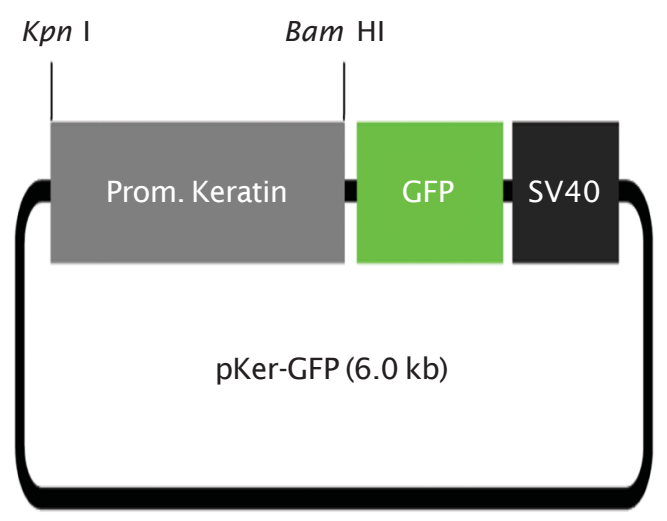

Gambar 1a. Peta plasmid pKer-GFP diperbanyak menggunakan bakteri $E$. coli strain DH5- $\alpha$.

Figure 1a. Map of plasmid pKer-GFP multipliedusing E. coli strain $\mathrm{DH} 5 \alpha$

Parameter yang diamati meliputi sintasan dan keberhasilan penyatuan gen warna yang disisipkan dalam individu ikan hasil transgenik. Pengukuran tingkat ekspresi gen GFP dilakukan pada titik puncak ekspresi gen pada titik ekspresi maksimum. Caranya adalah dengan mengelompokkan potongan sirip ke dalam 3 kelas ekspresi gen GFP berdasarkan luasan dan intensitas pendaran cahaya dari setiap ikan. Pengelompokannya adalah: tingkat 1 dicirikan dengan ekspresi pendar hijau kurang terang, tingkat 2 memiliki ekspresi pendar hijau terang, dan pada tingkat 3 ditunjukkan dengan ekspresi pendar hijau sangat terang. Setelah ikan berukuran sekitar $3 \mathrm{~cm}$, sirip ekor dipotong dan dilakukan ektraksi DNA untuk mengetahui individu ikan yang membawa gen GFP. Analisis data dilakukan secara dekriptif.

Plasmid pKer-GFP yang digunakan dalam transformasi gen penelitian ini adalah dikontrol oleh promoter dari spesies ikan Japanese flounder dan dikonstruksi oleh Yazawa et al. (2005), diintroduksikan ke Indonesia pada tahun 2008 oleh Dr. Alimuddin. Peta plasmid pKer-GFP ditunjukkan pada Gambar 1a. pKerGFP diperbanyak menggunakan bakteri E. coli strain $\mathrm{DH} 5 \alpha$ melalui transformasi dan isolasi plasmid sebelum digunakan untuk perlakuan. Gambar 1 a menunjukkan 4 klon bakteri yang mengandung plasmid pKer-GFP, $1 \mathrm{~b}$ menunjukkan hasil pengujian transformasi plasmid menggunakan PCR.

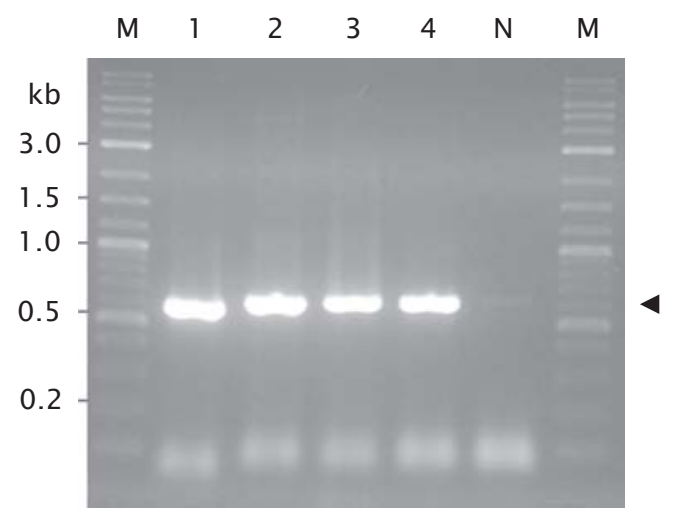

Gambar 1b. Peta plasmid pKer-GFP (kiri), dan pengecekan hasil transformasi plasmid pada 4 klon bakteri menggunakan PCR

Figure 1b. Map of plasmid pKer-GFP. (left), and testing of plasmid transfor-

\section{HASIL DAN BAHASAN}

\section{Motilitas Spermatozoa}

Motilitas spermatozoa setelah melalui kejutan arus sesuai perlakuan, dapat dilihat pada Tabel 1.

Dari hasil pada Tabel 1, terlihat bahwa penggunaan voltase yang berbeda berpengaruh secara nyata $(P<0,05)$ pada motilitas spermatozoa. Semakin tinggi voltase yang digunakan, semakin rendah motilitas sperma. Motilitas sperma yang dimaksud adalah jumlah spermatozoa yang masih aktif dalam satu populasi, bukan ketangkasan gerak individu.

Motilitas spermatozoa sangat dipengaruhi oleh media (cemen) baik secara fisika maupun kimiawi. Perubahan kimiawi pada cairan sperma juga dapat mempengaruhi motilitas sperma. Selain itu, motilitas sperma juga dipengaruhi oleh energi yang tersedia dan dapat dikonversi. Menurut Billard (1978), komposisi organik milt (seminal plasma) dari catfish dan carp mempunyai energi substrat seperti glukosa dan fruktosa, laktase, piruvat, malat, dan bahan lainnya dalam jumlah yang kecil pada spermatozoa. Berdasarkan tipe spermatozoa tersebut menyebabkan adanya beberapa perbedaan susunan kimia yang terkandung di dalamnya. Haubruge et al. (2000) mengatakan bahwa ikan carp dan catfish mempunyai biokimia spermatozoa dan proses spermatogenesis yang berbeda yaitu pada 
Tabel 1. Motilitas spermatozoa dari hasil perlakuan kejutan listrik dan kadar DNA yang berbeda

Table 1. Motility of spermatozoa resulted from different voltages and DNA consentrations

\begin{tabular}{ccccc}
\hline $\begin{array}{c}\text { Voltase } \\
\text { Voltage }\end{array}$ & $\begin{array}{c}\text { Konsentrasi DNA } \\
\text { Consentration DNA }\end{array}$ & $\begin{array}{c}\text { Waktu antara } \\
\text { Droop }\end{array}$ & $\begin{array}{c}\text { Voltase akt ual } \\
\text { Act ual Voltage }\end{array}$ & $\begin{array}{c}\text { Motilitas } \\
\text { Motility (\%) }\end{array}$ \\
\hline 50.00 & 10.00 & 5.00 & 49.00 & $80.00 \pm 13.23^{\mathrm{a}}$ \\
50.00 & 25.00 & 5.00 & 49.00 & $86.67 \pm 12.58^{\mathrm{a}}$ \\
75.00 & 10.00 & 5.00 & 73.00 & $75.00 \pm 5.00^{\mathrm{ab}}$ \\
75.00 & 25.00 & 5.00 & 73.67 & $65.00 \pm 13.23^{\mathrm{b}}$ \\
100.00 & 10.00 & 5.00 & 98.00 & $41.67 \pm 7.64^{\mathrm{c}}$ \\
100.00 & 25.00 & 5.00 & 98.00 & $36.67 \pm 2.89^{\mathrm{c}}$ \\
\hline
\end{tabular}

Keterangan: Huruf superscript yang berbeda dalam kolom yang sama menunjukkan perbedaan nyata $(\mathrm{P}<0,05)$

Note: Different superscripts in the same column show significant difference $(P<0.05)$

semen carp dapat dengan mudah dikeluarkan dengan cara di-stripping.

Medan elektromagnetik akan menyebabkan polarisasi ion pada cairan dan juga pada tubuh spermatozoa. Dengan demikian kekuatan medan elektromagnetik ini akan secara langsung mempengaruhi viabilitas dan motilitasnya.

Dari Tabel 1, menunjukkan bahwa dosis DNA yang digunakan tidak memberikan pengaruh yang nyata $(P>0,05)$ pada motilitas spermatozoa. Pengaruh dosis DNA secara terpisah pada motilitas tidak terpola, yang menunjukkan bahwa dosis DNA tidak menyebabkan turunnya motilitas. Demikian pula jika digabung antara dosis $10 \mu \mathrm{L}$ dan $25 \mu \mathrm{L}$, rataratanya tidak merubah nilainya secara nyata. Oleh karena itu, dapat dinyatakan bahwa motilitas spermatozoa hanya dipengaruhi oleh intensitas elektromagnetis dalam voltase yang digunakan (Gambar 2).

Keberhasilan pembuahan (fertilisasi) dapat didukung oleh kualitas spermatozoa yang baik, secara fisik maupun motilitasnya. Untuk mengetahui tingkat fertilisasi yang lebih tinggi, perlu dicari larutan fisiologis yang dapat menambah daya motilitas dan viabilitas spermatozoa. Menurut Rustidja (1985), penggunaan larutan fisiologis yang mengandung $\mathrm{NaCl}$ dan urea dapat mempertahankan daya hidup spermatozoa antara 20-25 menit.

Menurut Soehartojo (1995), di luar testis sel spermatozoa mampu memakai sumber energi dari luar untuk melanjutkan hidupnya. Bahan utama yang dipakai sebagai sumber energi dari luar adalah fruktosa yang akan diubah menjadi asam laktat dan energi dengan bantuan enzim fruktolisin. Pemberian larutan fruktosa sebagai pengencer untuk spermatozoa ikan dimaksudkan untuk memberikan energi dan nutrisi untuk spermatozoa ikan agar dengan energi yang berupa ATP tersebut dapat meningkatkan atau memperpanjang waktu motilitas dan viabilitas spermatozoa.

Di lain pihak kemampuan spermatozoa hidup secara normal setelah keluar dari testis hanya berkisar antara 1-2 menit. Menurut Suquest et al. (1993) dalam Cosson et al. (1999), bahwa di alam durasi motilitas terjadi dalam periode yang sangat pendek pada ikan air tawar. Billard dalam Jamieson (1990) menyatakan bahwa motilitas spermatozoa ikan dibatasi pada periode detik dan menit karena adanya osmotic injury.

\section{Hasil Penggabungan DNA pada Spermatozoa}

Sebagian sperma yang dihasilkan dari kejut listrik dianalisis untuk mengetahui inkorporasi plasmid pKer-GFP dalam sperma menggunakan metode PCR. Sebagian besar sperma ikan yang sudah dielektroforasi selanjutnya digunakan untuk membuahi telur. Hasil analisis PCR dengan DNA dari sperma ikan komet hasil elektroforasi ditunjukkan pada Gambar 3.

Hasil penggabungan DNA gen warna pada spermatozoa dapat diketahui dengan dua cara 


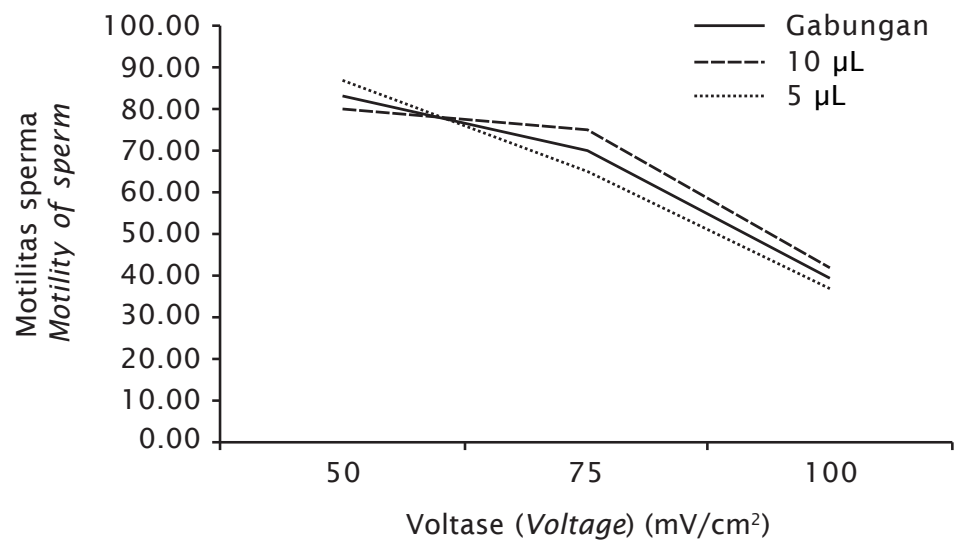

Gambar 2. Pengaruh pemakaian voltase pada elektroforasi terhadap motilitas spermatozoa ikan komet

Figure 2. Effect of voltage used in electroporation to the sperm motility of Carassius auratus

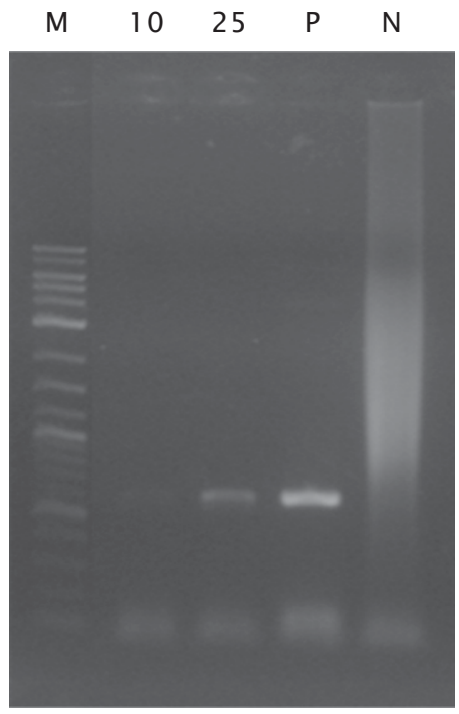

M : Marker ukuran fragmen DNA Marker of DNA fragment

10 : Dosis (dossage) $10 \mathrm{ng} / \mu \mathrm{L}$, Voltase (voltage) $100 \mathrm{mV} / \mathrm{s}$

25 : Dosis (dossage) $25 \mathrm{ng} / \mu \mathrm{L}$, Voltase (voltage) $100 \mathrm{mV} / \mathrm{s}$

P : Kontrol positif plasmid Positive control of plasmid

$\mathrm{N}$ : Kontrol negatif tanpa cetakan DNA Negative control without DNA template

Gambar 3. Hasil uji PCR DNA sperma komet yang telah dielektroforasi

Figure 3. PCR test of DNA spermatozoa treated with GFP by electrophoration

yakni menggunakan mikroskop flourescent dan pemindaian DNA. Pada Gambar 3 terlihat bahwa pada DNA dengan konsentrasi $25 \mu \mathrm{L}$ dan $10 \mu \mathrm{L}$ dengan voltage 100 volt terdeteksi GFP sedangkan untuk voltage $50 \mathrm{mV} / \mathrm{s}$ dan 75 $\mathrm{mV} / \mathrm{s}$ tidak keluar potongan pitanya. Penyebab tidak keluarnya pita dapat disebabkan karena proses ekstraksi yang tidak tepat atau konsentrasi DNA yang terlalu tinggi sehingga sulit annealing pada saat proses PCR.

\section{Jumlah Ikan}

Jumlah ikan hidup yang telah diberi perlakuan penyisipan gen GFP diamati mulai saat inkubasi sampai 24 jam. Jumlah telur yang menetas bervariasi bahkan ada yang sama sekali tidak menetas, dan ada yang menetas tetapi pada saat stadium larva banyak yang mati bahkan untuk kontrol tidak ada yang menetas. Hasil selengkapnya ditampilkan pada 
Tabel 2. Jumlah ikan yang hidup hasil penyisipan gen warna (GFP) dengan metode elektroforasi

Table 2. Total of survived fish resulted from introduced GFP gene done with electrophoration method

\begin{tabular}{ccc}
\hline $\begin{array}{c}\text { Voltase } \\
\text { Voltage }(\mathbf{m V} / \mathbf{s})\end{array}$ & $\begin{array}{c}\text { Konsentrasi DNA } \\
\text { Consentration of DNA }(\boldsymbol{\mu L})\end{array}$ & $\begin{array}{c}\text { Jumlah ikan yang hidup (ekor) } \\
\text { Total of life fish }(p c s)\end{array}$ \\
\hline 50 & 10 & 84 \\
75 & 10 & 86 \\
75 & 10 & 104 \\
100 & 10 & 123 \\
50 & 25 & 36 \\
75 & 25 & 18 \\
\hline
\end{tabular}

Tabel 2. Pada perlakuan konsentrasi DNA 25 $\mu \mathrm{L}$ dan voltasi 100 volt terjadi mortalitas $100 \%$.

Telur ikan komet pada panelitian ini berkualitas bagus, hal ini dibuktikan dengan derajat penetasannya yang tinggi, walaupun pada fase larva banyak yang mati, kecuali pada kontrol. Identifikasi telur adalah hal yang penting untuk mengetahui nilai derajat sintasan embrio telur kontrol maupun telur yang diberi perlakuan gen (injek atau elektroforasi).

Dari Tabel 2 menunjukkan bahwa jumlah ikan yang hidup dari hasil perlakuan dengan konsentrasi DNA yang berbeda tidak memiliki pola yang jelas. Artinya bahwa jumlah ikan yang hidup, bukan semata-mata pengaruh dari konsentrasi DNA, tetapi ada faktor lain selama embriogenesis maupun setelah ikan menetas.

\section{Ekspresi Gen pada Ikan}

Ekspresi sementara pada hasil korporasi DNA ke dalam spermatozoa melalui elektroforasi ikan komet dapat dilihat pada Gambar 4. Pada Gambar 4 benih ikan komet berumur sekitar 3 bulan yang sudah dapat dilihat bahwa ekspresi GFP yang disisipkan jelas terekspresi. Untuk membuktikan dan memastikan keberadaan GFP (DNA) pada benih ikan komet tersebut dilakukan PCR terhadap sirip ekor yang diambil sekitar $0,45 \mathrm{~g}$. Hasil dari PCR jaringan sirip menunjukkan semua positif membawa gen, tetapi harus dianalisis lebih lanjut untuk masing-masing individu.

Menurut Purwanti (2007), untuk mengetahui efektivitas suatu promoter, pada umumnya dilakukan dengan menyambungkan promoter dengan suatu gen lalu mengamati ekspresi sementara (transient) yang terjadi pada hewan uji. Selain itu, juga dapat dilihat ekspresi gen GFP pada sirip ikan yang membawa gen tersebut, walaupun tidak semua yang membawa gen GFP akan terekspresi secara sempurna.

Pada awalnya promoter keratin merupakan promoter yang digunakan pada teknologi transgenesis yang terkait dengan sistem imun, karena efektivitasnya yang tinggi pada jaringan kulit (Gong et al., 2002). Namun demikian efektivitas promoter keratin tidak hanya terbatas pada jaringan kulit dan epitel, tapi juga terdapat pada sel yang sedang berkembang dan sel saraf tertentu. Sedangkan Yazawa et al. (2005) menjelaskan bahwa promoter keratin yang diujikan pada ikan zebra mampu bersifat dapat aktif di mana-mana atau tidak spesifik jaringan tertentu (ubiquitous) dan dapat aktif kapan saja diperlukan (house keeping). Para peneliti telah melakukan karakterisasi promoter keratin pada berbagai jenis ikan, antara lain pada ikan rainbow trout (Markl et al., 1989), ikan koki, common carp (Groff et al., 1997), ikan hiu (Schaffeld et al., 1998), serta ikan zebra (Yazawa et al., 2005).

Houdebine \& Chourrout (1991) dalam Dunham (2004) menjelaskan bahwa ketika DNA asing diinjeksikan ke dalam sitoplasma, maka DNA asing tersebut mengalami proses replikasi dan dapat terekspresi dengan baik seiring dengan perkembangan embrio, namun kemudian perlahan ekspresi tersebut hilang pada fase perkembangan larva, pola ekspresi seperti ini pada umumnya disebut ekspresi sementara (transient). Ekspresi sementara 

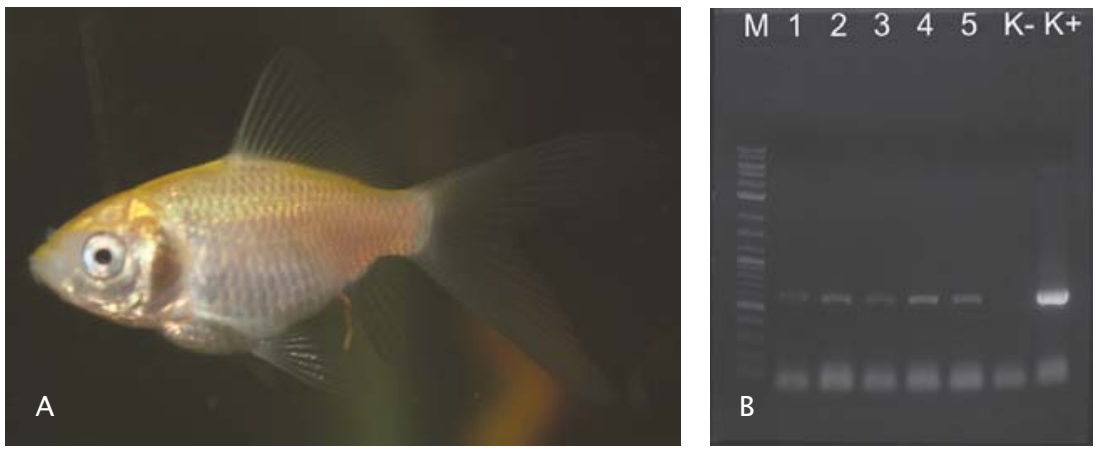

Gambar4. (A) Performa benih ikan yang telah diintroduksi dengan gen GFP menggunakan elektroforasi. (B) hasil PCR dari sirip ekor benih ikan komet yg berumur 3 bulan. $\mathrm{M}$ : marker; $\mathrm{K}(-)$ : kontrol negatif; $\mathrm{K}(+)$ : kontrol positif; 1 : dosis DNA $10 \mu \mathrm{L} / 50 \mathrm{mV} / \mathrm{s}$ ); 2. dosis DNA $25 \mu \mathrm{L} / 50 \mathrm{mV} / \mathrm{s}$ ); 3. dosis DNA 10 $\mu \mathrm{L} / 75 \mathrm{mV} / \mathrm{s}$ ); 4 . dosis DNA $25 \mu \mathrm{L} / 75 \mathrm{mV} / \mathrm{s}$ ); 5 . dosis DNA $10 \mu \mathrm{L} / 100 \mathrm{mV} / \mathrm{s}$ )

Figure 4. (A) Performance of fish introduced with GFP gene by electrophoration, (B) Result of PCR from caudal fin of 3 months old fish. $M$ : marker; $K(-)$ : negative control; $K(+)$ : positive control; 1 : dosage of DNA $10 \mu \mathrm{L} / 50 \mathrm{mV} / \mathrm{s}) ; 2$. dosage of DNA $25 \mu \mathrm{L} / 50 \mathrm{mV} / \mathrm{s}$ ); 3 . dosage of DNA $10 \mu \mathrm{L} / 75 \mathrm{mV} / \mathrm{s}$ ); 4. dosage of DNA $25 \mu \mathrm{L} / 75 \mathrm{mV} / \mathrm{s}) ; 5$. dosage of DNA $10 \mu \mathrm{L} / 100 \mathrm{mV} / \mathrm{s}$ )

sering terjadi pada beberapa penelitian transgenik, di antaranya pada ikan kakap, Sparus auratus (Garcia-Pozo et al., 1998), ikan zebra (Meng et al., 1999), ikan medaka (Winkler et al., 1990), ikan lele (Ath-thar, 2007), dan ikan mas (Purwanti, 2007).

Ekspresi gen sementara berhubungan erat dengan ketahanan dari DNA yang diinjeksikan atau dielektroforasikan (Lyengar et al., 1996). Tingginya ekspresi yang terjadi pada fase gastrula kemungkinan sebagai hasil dari akumulasi DNA yang diinjeksikan yang berlanjut pada peningkatan replikasi pada fase pembelahan (cleavage) dan akumulasi dari enzim (RNA polymerase II) yang menyebabkan dimulainya transkripsi pada saat MBT (midblastula transition). Lebih lanjut dijelaskan bahwa degradasi dari DNA pada saat fase lanjutan pada pembelahan sel diperkirakan akan menyebabkan penurunan bertahap dari jumlah DNA sehingga ekspresi sementara gen GFP akan semakin melemah.

Ekspresi sementara umumnya muncul setelah MBT, tergantung promoter yang digunakan. Pada penelitian ini, ekspresi sementara gen GFP pada larva mulai muncul pada saat tumbuhnya sirip. Sebenarnya pada fase gastrula sudah mulai muncul tetapi waktu itu tidak diamati, karena kekhawatiran ikan mengalami stres. Akhirnya pengamatan secara deskriptif dilakukan bertahap mulai umur 3 minggu sampai sirip sudah mulai panjang dan kemungkinan dapat dipotong untuk dilakukan PCR. Perbandingan yang lebih nyata sampai sekarang belum dapat terlihat jelas mengingat ikan masih kecil sehingga perpendaran warna yang diharapkan belum optimal. Ekspresi secara morfologi ikan komet sebelum dielektroforasi dengan setelah dielektroforasi dapat dilihat pada Gambar 5 .

Untuk mendapatkan ekspresi gen pada tahap $F_{0}$ dari penelitian ini masih menunggu sampai ikan komet menjadi induk dan matang gonad sehingga akan dilihat dengan PCR jaringan gonadnya untuk mengetahui ikan yang mana yang gen GFP di gamet, yang akan digunakan untuk memproduksi ikan transgenik keturunan pertama ( $\mathrm{F}-1)$.

Apabila dalam gonad ternyata terekspresi gen tersebut, maka ikan komet hasil elektroforasi nantinya akan disilangkan dengan ikan yang tidak diberi perlakuan dan sebaliknya. Hal tersebut dilakukan dengan maksud untuk mendapatkan F-1, apakah ekspresi gen GFP yang diijeksikan dapat diwariskan, dan seberapa persen nilai pewarisannya, serta ekspresi tersebut terdapat pada jaringan apa. Perlakuan tersebut berlangsung seterusnya F-2, F-3, dan seterusnya, dengan demikian hasil penelitian ini merupakan penelitian dasar 

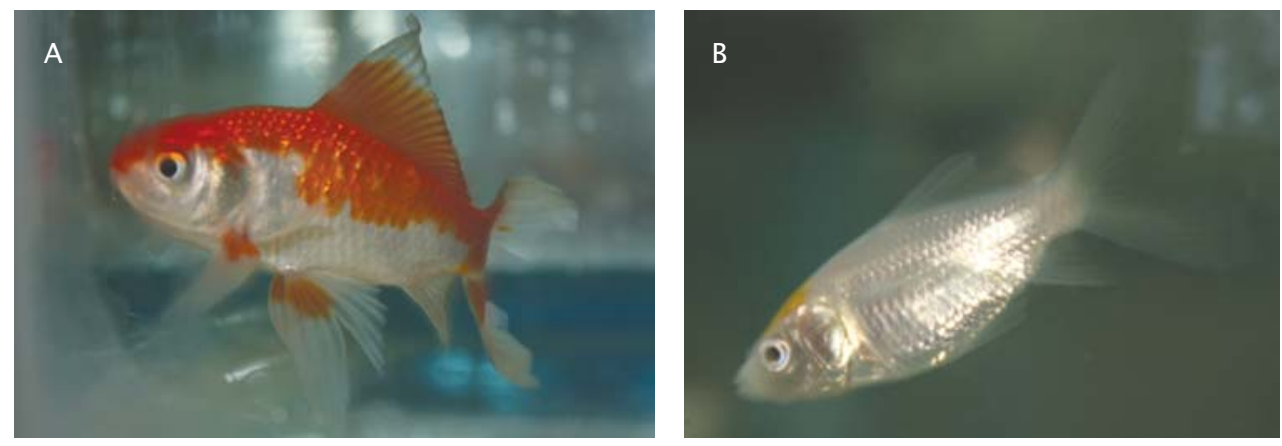

Gambar 5. Pengamatan visual untuk membedakan warna ikan komet: (A) tanpa penambahan gen GFP dan (B) sesudah dilakukan penyisipan gen GFP dengan elektroforasi

Figure 5. Visualization of fish to compare the color (A) without insertion of GFP gene, (B) fish with insertion of GFP gene by electrophoration

yang baru dapat melihat ekspresi gen pada benih ikan komet.

\section{KESIMPULAN}

1. Metode penyisipan (induksi) gen pemendar warna (GFP) dapat dilakukan menggunakan metode elektroforasi pada spermatozoa.

2. Elektroforasi untuk penggabungan DNA gen warna pada spermatozoa pada ikan komet dapat dilakukan menggunakan voltase antara 50 dan $100 \mathrm{mV} / \mathrm{cm}^{2}$ dengan konsentrasidNA $10 \mu \mathrm{L}$ dan $25 \mu \mathrm{L}$.

3. Gen pemendar warna (GFP) yang diinsersikan ke dalam telur melalui spermatozoa telah dapat diidentifikasi pada umur dua bulan dengan PCR dari ikan yang dihasilkan.

\section{DAFTAR ACUAN}

Ath-thar, M.H.F. 2007. Efektivitas promoter âactin ikan medaka Oryzias latipes dengan penanda gen hrGFP (Humanized Renilla reniformis Green Fluorescent protein) pada ikan lele Clarias sp. Keturunan FO. Skripsi. Departemen Budidaya Perairan. Perikanan dan Ilmu Kelautan. Institut Pertanian Bogor, $75 \mathrm{hlm}$.

Billard, R. 1978. Changes in structure and fertilizing ability of marine and freswater fish spermatozoa diluted in media of various salinities Aquaculture, 14: 187-198.

Collas, P., Husebeye, H., \& Alestrom, P. 2000. Transferring foreign genes into zebrafish eggs by microinjection. Transgenic Animal: Generation and Use, p. 119-122.
Cosson, J., Billard, R., Cibert, C., \& Dreanno, C. 1999. Ionic Factor regilating theMotility of fish sperm. Villefranch. France, p. 1,2381,243 .

Dunham, R.A. 2004. Aquaculture and Fisheries Biotechnology: Genetic Approaches. CABI Publishing. Cambridge, MA, USA, 380 pp.

Garcia-Pozo, S., Bejar, J., Shaw, M., \& Alvarez, M.C. 1998. Effect of exogenous DNA microinjection on early development response of the seabream Sparus aurata. Molecular Marine Biology and Biotechnology, 7(4): 248-257.

Gong, Z., Wan, H., Ju, B., He, J., Wang, X., \& Yan, T. 2002. Generation of Living Color Transgenic Fish. In: Shimizu, N., Aoki, T., Hirono, I., \& Takashima, F. (eds) Aquatic Genomics: Steps Toward a Great Future. Springer-Verlag. New York, p. 329-339.

Groff, J.M., Naydan, D.K., Higgins, R.J., \& Zinkl, J.G. 1997. Cytokeratin filament expression in epithelial and non-epithelial tissues of the Common Carp (Cyprinus carpio). Cell Tissue Res., 287: 375-384.

Hackett, P.B. 1993. The Molecular Biology of Transgenic Fish. In: Hocachka and Mommesen (Eds.). Biochemistry and Molecular Biology of Fishes. Elsevier Science Publishers BV., 2: 218-221.

Haubruge, E., Petit, F., \& Gage, M. 2000. Reduced sperm counts in guppies (Poecilia reticulata) following exposure to low levels oftributyltin and bisphenol. Proc. R. Soc. Biol. Ser. B., 267: 2,333-2,337.

Jamieson, B.G.M. 1990. Fish Evolution and Systematics: Evidence from Spermatozoa 
(With a survey of lophophorate, echinoderm and protochordate sperm and an account of gamete cryopreservation. Cambridge University Press. New York, 22 pp.

Kinoshita, M. \& Ozato, K. 1995. Cytoplasmic microinjection of DNA into fertilized medaka Oryzias latipes eggs. The Fish Biology J. MEDAKA, 7: 59-64.

Lyengar, A., Muller, F., \& Maclean, N. 1996. Regulation and expression of transgenes fish A Review. Transgenic Research, 5: 147-166.

Markl, J., Winter, S., \& Franke, W.W. 1989. The catalog and the expression complexity of cytokeratins in lower vertebrate: Biochemical identification of cytokeratins in a teleost fish, Rainbow trout. Eur. J. Cell. Biol., 50: 1-16.

Meng, A., Jessen, J.R., \& Lin, S. 1999. Transgenesis. Methods in Cell Biology In : Detrich HW III, Westerfield, M. \& Zon, LI (eds.) 60: 133-148.

Purwanti, L.I. 2007. Uji Efektivitas Promoter âactin Ikan Medaka Oryzias latipes dengan Penanda Gen hrGFP (Humanized Renilla reniformis Green Fluorescent protein). Skripsi. Departemen Budidaya Perairan. Perikanan dan IImu Kelautan. Institut Pertanian Bogor, $97 \mathrm{hlm}$.
Rustidja. 1985. Pengantar Ilmu Repoduksi Ikan. Fisheries Project Unibraw. Malang, $138 \mathrm{hlm}$.

Schaffeld, M., Lobbecke, A., Lieb, B., \& Markl, J. 1998. Tracing keratin evolution: catalog, expression patterns and primary structure of Shark (Scyliorhinus stellaris) keratins. Eur. J. Cell. Biol., 77: 69-80.

Soehartojo, H. 1995. Ilmu Kemajiran Pada Ternak. Airlangga University Press. Surabaya, $120 \mathrm{hlm}$.

Suquest, M., Dorange, G., Omnes, M.H., Normant, Y., Le Roux, A., \& Fauvel, C. 1993. Composition of the seminal fluid and ulrastructure of the spermatozoon of turbot (Scophtalmus maximus). J. Fish Biol., 42: 509-516.

Winkler, C., Vielkind, J.R., \& Schartl, M. 1990. Transient expression of foreign DNA during embryonic and larval development of the Medaka fish Oryzias latipes. Mol. Gen. Genet., 226: 129-140.

Yazawa, R., Hirono, I., \& Aoki, T. 2005. Characterization of promoter activities of four different Japanese Flounder promoters in transgenic Zebrafish. Marine Biotechnology, 7: 625-633. 